Stirling Management School

Industrial composition, methods of compensation, and real earnings in the Great Depression

Robert A. Hart

J. Elizabeth Roberts

Stirling Economics Discussion Paper 2013-03

February 2013

Online at

http://www.management.stir.ac.uk/research/economics/workingpapers 


\title{
Industrial composition, methods of compensation, and real earnings in the Great Depression
}

\author{
Robert A. Hart \\ Division of Economics, University of Stirling and IZA \\ Email: r.a.hart@stir.ac.uk \\ J. Elizabeth Roberts \\ Division of Economics, University of Stirling \\ February, 2013
}

JEL Classification: E32, J31, J33, N64

Keywords: Industrial composition, piecework, timework, real earnings, the Great Depression

\begin{abstract}
In an extension of an earlier paper (Hart and Roberts, 2012), we investigate the pay and working time of blue-collar timeworkers and pieceworkers during the Great Depression within British engineering firms. We compare and contrast southern/midland engineering districts of Britain with northern districts. The south/midlands region was dominated by piece-rated workers and by modern sections of the industry, such as vehicle and aircraft manufacture. Time-rated work predominated in northern districts where older sections - for example, marine and textile engineering - were clustered. These contrasting industrial compositions and associated payment methods offer further insights into manufacturing real earnings responses to the Great Depression.
\end{abstract}

Acknowledgements: This work was funded by ESRC Grant RES-000-22-3574. We are grateful to the Engineering Employers' Federation (EEF) for allowing access to their payroll records and to Warwick University Modern Record Centre and Glasgow University Archive Centre for their help in assembling the data and to Andrew Currall for his excellent work in data transcription. The full EEF data base, containing all EEF data and accompanying unemployment rates used in this project, is available at the UK Data Archive, Study 5569 (http://www.esds.ac.uk/findingData/snDescription.asp?sn=5569). 
"Engineering, while concerned chiefly with metal manufacture, is an industrial colossus: its products range from gasometers to jet engines, cathode ray tubes to combine harvesters, and telephones to tanks" (Knowles and Hill, 1954, p. 308)

\section{Introduction}

In an earlier paper (Hart and Roberts, 2012) we presented evidence on the real wage cyclicality of blue collar workers during the Great Depression in Britain's most important manufacturing industrial sector, engineering and metal working. Using payroll data of member firms of the Engineering Employers' Federation (EEF) between 1927 and 1937, we establish that the hourly real wages of time-rated workers were acyclical while those of piece-rated workers were significantly, though modestly, procyclical. Both pay groups displayed significant and strong procyclicality in weekly real earnings.

We extend our earlier study by exploring the implications for wage and hours cyclicality of the considerable differences in the composition of engineering production in southern and midland geographical engineering districts of Britain compared with northern districts. For the large part the most modern and expanding sections of the industry were located in the south and midlands. These included motor vehicles, aircraft manufacture, machine tools and electrical engineering. Throughout the Depression, these districts enjoyed the highest EEF earnings and experienced the lowest district unemployment rates (Hart and MacKay, 1975, Table 5). In contrast, older declining sections of the industry were largely confined to northern districts. These included marine engineering, textile machinery and agricultural machinery. Moreover, 
in both north and south, specific engineering sections tended to cluster within specific districts. Coventry and the West Midlands were most associated with motor vehicle production, North West Scotland and the North East Coast of England with marine engineering, and various districts in Lancashire and Yorkshire with textile machinery.

This north-south divide in production orientation was reinforced by differences in the payment methods in respect of the two regional workforces. In our complete national EEF data, $53 \%$ of workers were paid piece rates and $47 \%$ time rates. ${ }^{1}$ The incidence of piece rate payments was at least as important as that of time rates in the EEF throughout the first half of the Twentieth Century. In a broader context, piece rates applied to about two-thirds of skilled and semi-skilled workers in engineering and metal working in both Britain and Germany in the early 1930s (Hart and Roberts, 2012). The literature on the subsequent long-term demise of piece rate systems, given major changes in manufacturing techniques and organisation, includes Helper, Kleiner and Wang (2010), and Arrowsmith and Marginson (2010) for Britain. ${ }^{2}$

The incidence of timeworking was more important among the northern workforce and pieceworking more important in the south and midlands. This is shown in Figure 1. In 1927, pieceworkers comprised $53 \%$ of total workers in the

\footnotetext{
${ }^{1}$ These percentages cover all EEF districts. In the analysis here, we concentrate on the sub-set of districts for which we have matching unemployment rates.

${ }^{2}$ For example, the advent of just-in-time systems in modern manufacturing was intended in part to minimise inventories. Parts suppliers are required to meet specified output quantities within given time frames. There is no incentive to exceed production quotas by encouraging higher output levels through payments by results schemes.
} 
southern/midland districts compared to $37 \%$ in northern districts. By 1937 , the respective percentages had risen to $68 \%$ and $58 \% .^{3}$ The overall rises in the pieceworker shares were not monotonic. In both regions they dipped slightly in 1930 followed by strong increases in 1931 and 1932.

Here, we investigate the implications for pay cyclicality of these geographical differences in industrial composition and in payment methods. We find that the real weekly real earnings for both pay groups in both regions were strongly procyclical. But the cyclicality for the main components of weekly pay was not uniform. Hourly real earnings of timeworkers, both north and south, were more or less acyclical.

Timeworkers' payroll costs were reduced principally through strongly procyclical changes in weekly paid-for hours. The weekly paid-for hours of pieceworkers were also procyclical, but less strongly so than those timeworkers. Unlike timeworkers, the real hourly pay of pieceworkers was procyclical and significantly more so in southern/midland engineering districts. We argue that this resulted, primarily, from the fact that piecework remuneration in core growth sections like vehicle production was strongly conditioned by productive effort per unit of time.

\section{Engineering industrial and workforce compositions in the 1930s}

By the mid-1930s, British engineering had experienced two large industry-wide changes. The first was both longer term and structural. The previous thirty years had

${ }^{3}$ The data include labourers for whom piece rates were less common than for skilled and semi skilled blue collar workers. 
witnessed marked expansions in new sections of the industry. The main growth occurred in vehicle production, aircraft manufacture, electrical engineering, and machine tools. These sections were principally located in southern and midlands engineering districts. Older, more traditional sections -including marine engineering, textile engineering, and agricultural machinery - were in secular decline and were largely confined to northern districts. ${ }^{4}$ The second change was cyclical, sudden, and relatively short-lived. The Great Depression witnessed a severe drop in output demand and in product prices that started in late 1929 and continued to 1934 . Given their favourable sectional compositions, southern/midland engineering districts were better shielded against the most severe cutbacks in production and employment.

The better fortunes of the south were reflected on companies' intensive and extensive margins. On intensive margins, weekly hours of work in the EEF were everywhere procyclical. However, Figure 2 shows that in the first stages of the Depression cycle short time working among both timeworkers' and pieceworkers' - i.e. weekly hours less than the maximum 47 hours - was a considerably greater phenomenon in the north. On extensive margins, there was a greater propensity to layoff workers in northern engineering districts. Figure 3 shows that unemployment rates in northern districts were substantially higher than in southern/midland districts. By 1932 , the unemployment rate in the former was $32 \%$ compared with $18 \%$ in the latter.

\footnotetext{
${ }^{4}$ EEF engineering districts belonging to these two broad regions are reported in Table 1 together with the blue collar occupations included in the present study.
} 
Based on timeworkers, Table 2 illustrates pay and hours implications of the compositional diversity across EEF districts and sections. In the midlands, Coventry was the epicentre of modern engineering activity, playing a central role in motor and cycle manufacture, airframe manufacture, and machine tools. In the north, the North East Coast and Halifax were districts in which older engineering activity took place. The former included marine engineering and the latter textile machine manufacture and repair. Accordingly, Table 2 also includes three representative engineering sections for the three districts: vehicles and cycles, marine engineering, and textile machinery. ${ }^{5}$

Differences in labour and production performances are illustrated by recovery rates in real standard hourly wages and in hours of work in the post-Depression years of 1934-1937 compared to the Depression years, 1930-1933. Coventry's average real wage growth was $11.6 \%$ in contrast to $7.1 \%$ in the North East Coast, and $4.6 \%$ in Halifax. Since Coventry was less affected by the Depression than the other two districts (see Hart and MacKay, 1975, Table 5), we find that it experienced a mere $3 \%$ rise in weekly hours between the two periods in contrast to $8.7 \%$ and $16 \%$ increases in the North East Coast and Halifax, respectively. ${ }^{6}$ The relative wages and hours changes in respect of the associated sections reveal a comparable picture: the vehicle section displayed far more resilience than the two more traditional engineering sections.

\footnotetext{
${ }^{5}$ Note, however, that the sections refer to all relevant engineering districts nationwide. We do not have EEF section data by district.

${ }^{6}$ Coventry's unemployment rate during the Great Depression peaked in 1931 at 18.1\%; Halifax's rate peaked at $24.6 \%$ in the same year while the North East Coast peaked at 43.1\% in 1932.
} 
Why was there a greater incidence of pieceworking in the south/midlands and of timeworking in the north (see Figure 1)? Almost certainly, this is closely linked to distinct clusters of sectional engineering activities within districts in these two broad geographical areas. For example, many EEF companies in the south and midlands were involved in vehicle production. ${ }^{7}$ The expanding demand for vehicles and vehicle parts necessitated long production runs that required large-scale supplies based on the same designs. This type of small-parts production orientation was conducive to payments-byresults remuneration via piece rate pricing on products that were amenable to monitoring for quality and quantity (see Helper, Kleiner and Wang, 2010). ${ }^{8}$ By contrast, the production of marine engines in the north of Britain entailed more specialised parts manufacture and assembly. Engineering job tasks on more complex heavy engineering products almost certainly involved higher degrees of multi-tasking among the bluecollar workforce as well as outputs that were costly to quantify and, therefore, more likely to be conducive to a fixed-wage system (see Holmstrom and Milgrom, 1991).

Table 3 shows the percentages of pieceworkers to all blue-collar workers by the engineering sections covered in our EEF data sample. Four of the top-five ranked sections relate to vehicles and aircraft manufacture and these were all predominantly located in midlands and southern districts. It should be added that pieceworking is strongly represented in all sections - apart from lamp manufacture. So while sections

\footnotetext{
${ }^{7}$ The EEF was strongly represented in all major British car companies and in their main parts suppliers.

${ }^{8}$ Long production runs were an especially important consideration since they reduced the frequency, and associated costs, of negotiating piece rates.
} 
like textile machinery and marine engineering were heavily concentrated in the north, pieceworkers nonetheless accounted for roughly half of their workforces.

\section{The structures of timework and piecework earnings in the EEF}

In this section we show the main component parts of timeworkers' and pieceworkers' weekly earnings, highlighting potential interactions with business cycle fluctuations. In addition to the earnings elements incorporated here, remuneration incorporated a National Bonus payment. ${ }^{9}$ There was also a wide variety of supplementary payments. ${ }^{10}$ Examples include 'dirty money' (wage supplements to compensate for adverse working conditions), merit awards, and compensatory bonuses. $^{11}$

\footnotetext{
${ }^{9}$ The National Bonus was first paid in 1917 in order to compensate engineering workers for exceptional cost of living increases during WWI. While it was intended to be a temporary pay supplement and while it was significantly reduced in 1922, it was not consolidated into basic rates of pay until 1950. In 1927, timeworkers, but not pieceworkers, received a 20\% Bonus increase. Further money increases in 1935, 1936 and 1937 applied equally to both timeworkers and pieceworkers. All four changes served to reduce piecework-timework minimum expected pay differentials. While we refer to the Bonus in this section, in order to avoid undue detail, we do not explicitly highlight it in our definitions of timework and piecework earnings. Detailed analyses of the inter-war and immediate post-war EEF earnings structure, including the contribution of the National Bonus, are given by Knowles and Robertson (1951) and Knowles and Hill (1954).
}

${ }^{10}$ We make no attempt to incorporate the roles played by supplementary payments. They became more important prior to WWII, through the war, and in the immediate post-war years. See Knowles and Hill (1954, Table IX).

${ }^{11}$ Compensatory bonuses were paid to timeworkers whose work was deemed to add value above average but who, unlike pieceworkers, were not eligible to receive payments directly related to performance. 
Average timeworkers' weekly earnings for occupation $j$ in engineering district $d$ at time $t$ is given by

(1) $E_{j d t}=e_{j d t} H_{j d t}$

where $E$ is average weekly earnings, $e$ is average hourly earnings, and $H$ is average weekly paid-for hours.

Overtime working was an important feature of weekly working time and given that hourly overtime pay differed from standard time pay we need to distinguish between the two types of hours. Let $H=H_{S}+H_{O}$ where $H_{S}$ is standard weekly hours paid for at basic rates and $H_{O}$ is overtime weekly hours to which a premium rates applied. Maximum EEF weekly standard hours were 47 and so $\mathrm{H}_{\mathrm{O}}>0$ if $\mathrm{H}>47$. Let $\theta=H_{S} / H$ in which case $\theta<1$ if $H_{S}<\left(H_{S}+H_{O}\right)$ and $\theta=1$ if $H_{S}=H$. Then $(1-\theta)$ defines the share of overtime in weekly hours. Incorporating this share, it is useful to approximate hourly earnings using a geometric average. We have

(2) $e_{j d t}=w_{j d t}^{\theta_{j d t}}\left(k_{t} w_{j d t}\right)^{\left(1-\theta_{j d t}\right)}$

where $w$ is the basic hourly time rate ${ }^{12}$ and $k$ is the overtime premium. Local-level basic time rates were generally related to nationally-negotiated time rates for skilled fitters and unskilled labourers. However, company- and district-level interpretations of occupational wage relativities could vary widely. More national uniformity was achieved in respect of maximum weekly standard hours and the overtime premium. Both

\footnotetext{
12 The basic time rate was supplemented by the National Bonus to create a so-called actual or effective rate. Here, we ignore the Bonus add-on.
} 
maximum $H_{S}$ and $k$ were set nationally and applied to all workers in the EEF (i.e.

timeworkers and pieceworkers). Maximum $H_{s}$ remained fixed at 47 hours throughout our period while $k$ was altered once, in 1931.

Substituting (2) into (1), taking logs and differentiating with respect to national unemployment $\left(U_{t}\right)$ to represent the cycle ${ }^{13}$, gives

(3) $\frac{\partial \ln E_{j d t}}{\partial U_{t}}=\frac{\partial \ln w_{j t}}{\partial U_{t}}+\left(\ln k_{t}\right) \frac{\partial\left(1-\theta_{j d t}\right)}{\partial U_{t}}+\left(1-\theta_{j d t}\right) \frac{\partial \ln k_{t}}{\partial U_{t}}+\frac{\partial \ln H_{j d t}}{\partial U_{t}}$.

Pieceworkers' weekly earnings involved more complicated considerations. They depended on a multitude of piecework prices applied to a considerable diversity of products, processes and operations. As well as the number of hours per week, they were also dependent on productive effort per hour. Overtime pay applied along the same lines as timeworkers. In principle, much of the complexity derived from the fact that piece rates and time settings were established at local levels. In practice, starting in 1914 , attempts were made to simplify hourly piecework pay by linking it to equivalent time rates via national employer-union agreements. First, a pieceworker was guaranteed the basic equivalent time rate. Secondly, a pieceworker of 'average ability' in a given occupation was expected to receive a minimum hourly basic wage rate that was at least $33^{1} \frac{1}{3}$ per cent over the equivalent basic time rate. This was referred to as

\footnotetext{
${ }^{13}$ In the earnings estimation in Section 5 we use both national and district-level unemployment rates.
} 
the piecework percentage, which we label $p$ - $p$. From June 1931 to March 1943, the $p-p$ was reduced to 25 per cent of the basic time rate. ${ }^{14}$

The $p-p$ had the advantage of providing a target, recognised throughout the industry, by which the basic hourly wages of typical pieceworkers might be expected to exceed the equivalent timeworker rates. It also helped to set piecework prices: these were adjusted so that the piece rate percentages were achieved. Piece rate prices and times were set at local levels. For given pieceworker occupations, deviations from nationally agreed time rates and from the $p$ - $p$ could well occur. However, even allowing for local pay variations, the system had a major limitation. Changes nationally agreed basic time rates or in the $p-p$ implied considerable costs of adjusting a vast number of linked piecework prices. ${ }^{15}$

There remains a fundamentally important aspect of piecework remuneration. Unlike timeworkers, hourly pay of pieceworkers is dependent on their output per hour. Suppose that, under given business expectations, piece-rates were set such that a pieceworker may expect to earn $\mathrm{x} \%$ per hour more than an equivalent time worker. An unanticipated fall in output demand involves two potential intensive margin cost-cutting

\footnotetext{
${ }^{14}$ It is important to note that the $p$ - $p$ did not imply that, as a minimum, a typical pieceworker could expect to earn one-third or one-quarter more than an equivalent timeworker. A pieceworker's effective minimum rate of pay consisted of the basic time rate plus the $p-p$ plus the National Bonus. A timeworker's effective minimum rate of pay consisted of the basic time rate plus the National Bonus. The National Bonus payment ensured that the effective minimum rates' differential was less than the $p-p$.

${ }^{15}$ See Knowles and Hill (1954, especially p. 284 and p. 302). In fact, it was argued that piecework pay differentials were best adjusted via changes in the National Bonus since this side-stepped the problems of piece rate price adjustments.
} 
reactions by employers. First, weekly hours could be reduced. Second, output per person-hour could be reduced by slowing the rate of production throughput. Only the first of these two cost objectives was feasible, at least in the short-run, in the case of timeworkers.

As shown in Table 3, vehicle production was dominated by piecework. It offers an obvious example of a section in which hourly productivity might fluctuate since the batch production of car and truck parts among suppliers was in important respects controlled by changes in the per-period rates of vehicle assembly. A persuasive example is given by Knowles and Hill (1954, pp. 310/311) in respect of car production in EEF companies between 1948 and 1953. "Motor car production reached a peak in the export boom of 1950, fell off in 1951-52 when the export market collapsed and steel supplies were short, and rose very steeply in 1952-53 when the steel shortage had eased. Pieceworkers' average hourly earnings in motor cars were responsive to this fluctuation: they increased much more than the average between 1948 and 1951....., in 1951-52 their rise was below average; while in 1952-53 it was again easily the largest of any section." These authors further report that, over this period, employment was static and "fluctuations in hours worked in this section were not nearly sufficient to offset the fluctuations in production". They conclude that hourly earnings fluctuations derived principally from variations in hourly productivity.

Pooling together these various piecework pay components, and recognizing that we are offering no more than an approximation to actual piece rate setting in many 
local districts, average pieceworkers weekly pay for occupation $j$ in district $d$ at time $t$ is given by

(4) $P_{j d t}=\left(\left(p_{j d t}\right)^{\phi_{j d t}}\right) H_{j d t}, \quad 0<\phi \leq 1$

where $P$ is average weekly earnings, $p$ is average hourly earnings. The parameter, $\phi$, represents hourly productive work intensity. For simplicity we assume that $\phi=1$ represents optimal intensity of effort - such as the agreed line speed in a car assembly plant in the face of a healthy order book - while $\phi<1$ represents short-run periods in which productive effort falls short of this optimum due to unanticipated demand reductions. For any given value of $\phi$, work intensity is assumed constant across all weekly hours. ${ }^{16}$

Average hourly piecework earnings are given by

(5) $p_{j d t}=\left(m_{j d t} w_{j t}\right)^{\theta_{j t}}\left(k m_{j d t} w_{j t}\right)^{\left(1-\theta_{j t}\right)}$, where $m$ is a percentage piece rate markup. The markup is made up of two parts, that is

(6) $m_{j d t}=(p-p)_{t}+\delta_{j d t}, \quad \delta \gtreqless 0$, where $\delta$ is the district deviation from the national piecework percentage, $p-p$.

Substituting (5) into (4) taking logs and differentiating with respect to national unemployment $\left(U_{t}\right)$, gives

\footnotetext{
${ }^{16}$ We ignore individuals' supply-side reactions to company-led required changes in effort due to product demand fluctuations.
} 


$$
\text { (7) } \begin{aligned}
\frac{\partial \ln P_{j d t}}{\partial U_{t}}= & \phi_{j d t}\left[\frac{\partial \ln w_{j d t}}{\partial U_{t}}+\frac{\partial \ln m_{j d t}}{\partial U_{t}}+\left(\ln k_{t}\right) \frac{\partial\left(1-\theta_{j d t}\right)}{\partial U_{t}}+\left(1-\theta_{j d t}\right) \frac{\partial \ln k_{t}}{\partial U_{t}}\right] \\
& +\frac{\partial \phi_{j d t}}{\partial U_{t}}\left(\ln p_{j d t}\right)+\frac{\partial \ln H_{j d t}}{\partial U_{t}} .
\end{aligned}
$$

During periods when $\phi=1$, and so $\frac{\partial \phi_{j d t}}{\partial U_{t}}=0$, pieceworkers' (potential) cyclical responses are confined to changes in wage earnings and weekly hours. Where there is no such binding constraint then $\frac{\partial \phi_{j d t}}{\partial U_{t}}<0$ or productive work intensity is procyclical.

For timeworkers and pieceworkers in (3) and (7), changes in basic time rates, the overtime premium, the share of overtime, and total weekly hours had potential cyclical impacts on weekly earnings. Additionally, the cyclicality of pieceworkers' earnings could be affected by changes in piecework percentage and in hourly productivity.

\section{EEF Data}

We make use of EEF member firms' payroll data for the period 1927-1937. Detailed data descriptions are provided by Hart and Roberts (2012). During our period of study, the Federation represented between 1,800 and 2,200 firms employing between 390,000 and 520,000 adult male manual workers (Wigham, 1973, Appendix, J). Our wages and hours data cover manual male timeworkers and pieceworkers over the age of 21 in 14 blue-collar occupations. The payroll data are collected in October of each year. The wages data cover hourly basic wage rates, hourly earnings, weekly hours, and weekly earnings. For any given wage or hours definition, we construct cell 
means where each cell identifies whether the worker is paid time rates or piece rates, his occupation, and his work district.

In the complete EEF dataset (see Acknowledgements) there are 51 engineering districts. Here, we make use of a sub-set of 28 districts for which we have matching annual unemployment rates: together, they account for $85 \%$ of the total sample EEF labour force in the full data set. Table 1 shows the 14 occupations and the division of the 28 districts as between the north and south/midlands.

\section{Piecework-timework hourly earnings differentials}

Pieceworkers' rates of pay in the EEF were higher than those of equivalent timeworkers, a finding common to the literature (e.g., Pencavel, 1977; Seiler, 1984). For example, more able individuals opt into piece-rated jobs since they know that they can earn more per unit of time than in equivalent time-rated jobs. What happened to the piecework-timework hourly earnings differentials over the Great Depression cycle?

Using our complete data, we estimate the path of the piecework-timework hourly earnings differential after conditioning for occupations, districts, and time. The differential is given by

(8) $\ln p_{j d t}-\ln e_{j d t}=Z_{j d t} \theta+e_{j d t}$

where $Z$ represents a set of controls consisting of occupation dummies, district dummies, and year dummies. We estimate equation (8) in two ways: we show hourly earnings that (a) include the effects of overtime, and (b) exclude the effects of 
overtime. ${ }^{17}$ The estimated annual differentials for the two earnings series are shown in Figure 4 - they are the plots of the estimated year dummies in equation (8). The piecetime hourly earnings differentials narrowed appreciably between 1929 and 1932 when the most severe downturn of the Depression occurred. The outcomes are virtually identical whether or not we adjust for the effects of overtime.

Does the pattern in Figure 4 hold when we split the data into northern and southern/midland districts? The answer is yes, and this is illustrated in Figure 5 in respect of turners using their overtime-corrected hourly earnings. This is a major engineering occupation with a large representation in the two sets of districts. The differentials coincide closely, falling from about $21 / 22 \%$ in 1930 to a trough of under $13 / 15 \%$ by $1932 / 33$ before climbing to about $17 \%$ by 1937 . This pattern is common across occupations.

In Section 3, we noted two national level agreements reached in 1931 that served to narrow the differentials. First, the piecework percentage was reduced from one-third to one-quarter above the equivalent basic time rate. Second, the overtime premium in respect of the first two hours of daily overtime was reduced from time and a

${ }^{17}$ From Figure 2 we know that the length of timeworkers' weekly hours exceeded those of pieceworkers. Without correcting for overtime, hourly earnings differentials can, therefore, partially reflect different shares of overtime hours within total hours. We adjust for overtime by multiplying hours above 47 weekly hours by the appropriate overtime premium rates. These corrected hours are then divided into total weekly earnings to obtain standard-equivalent earnings differentials. Actually, this only provides approximate estimates since overtime pay in the EEF was paid in respect of daily hours worked and so was conditioned in part by the distribution of daily hours. We adopt the approximation in our calculations due to the absence of data on daily hours. 
half to time and a quarter. We note, however, that while the earnings differentials declined in 1931 - to some extent influenced by these policy changes - they had declined even more steeply in the preceding two years. Also, post-1932 the differentials rose despite the fact that, as noted in footnote 9 , the National Bonus increases from 1935 to 1937 acted in favour of timeorkers' earnings.

\section{Real earnings cyclicality and the north-south divide}

Wages and hours regressions are undertaken separately for pieceworkers and timeworkers. Following the discussions in Sections 2 and 4, we want to test for differences in pay and hours responses to the Great Depression business cycle between northern engineering districts and southern/midland districts. Accordingly, we define a binary variable $D$ such that

(9) $D_{t}=1$ for northern districts at time $t$,

$$
=0 \text { otherwise. }
$$

Our pay and hours estimating equations incorporate $D_{t}$ to allow for differences in the pay reactions of northern and southern/midland hourly earnings to the Great Depression business cycle. We use both national and district-level unemployment rates to proxy the cycle. We illustrate our regression equations on the basis of hourly earnings, expressed $e=E / H$ and $p=P / H$ (see Section 3). 
Let $\Delta e$ be annual first-differenced hourly real earnings of timeworkers and $\Delta p$ be the equivalent for pieceworkers. For occupation $j$ in district $d$ at time $t$, our regressions based on national unemployment are given by

$$
\Delta e_{j d t}=\alpha_{1} \Delta U_{t}+\alpha_{2} \Delta U_{t} D_{t}+\alpha_{3} D_{t}+Z_{j d t} \theta_{1}+\varepsilon_{j d t}
$$

$$
\Delta p_{j d t}=\beta_{1} \Delta U_{t}+\beta_{2} \Delta U_{t} D_{t}+\beta_{3} D_{t}+Z_{j d t} \theta_{2}+\omega_{j d t}
$$

where $\Delta U_{t}$ is the first-differenced national unemployment rate, $\Delta U_{t} D_{t}$ is a slope dummy, and $Z_{j d t}$ is a set of controls consisting of occupation dummies, district dummies, and a time trend. Given we have annual occupational hourly earnings that are regressed on a single national rate of unemployment, potential standard error biases are countered by clustering at the year level. Real hourly earnings are obtained using a final output price deflator obtained from Feinstein (1972). Reported estimates are weighted by the numbers of workers in each annual occupational earnings cell.

Our regressions incorporating district-level unemployment rates are given by

$$
\Delta e_{j d t}=\alpha_{1} \Delta U_{d t}+\alpha_{2} \Delta U_{d t} D_{t}+\alpha_{3} D_{t}+Z_{j d t} \theta_{1}+\varepsilon_{j d t}
$$

$$
\Delta p_{j d t}=\beta_{1} \Delta U_{d t}+\beta_{2} \Delta U_{d t} D_{t}+\beta_{3} D_{t}+Z_{j d t} \theta_{2}+\omega_{j d t}
$$

where unemployment rates are now further delineated by districts, and $Z_{j d t}$ contains occupation, district, and year dummies. Given we have up to 14 occupational earnings rates per district we counter potential standard error biases by clustering at the district/year level. Real hourly earnings derive from controlling for both districts and 
year fixed effects. Reported estimates are weighted by the numbers of workers in each occupation cell at district level.

Additionally, we recognise that the error terms between the foregoing pairs of pieceworker and timeworker regressions are likely to be contemporaneously correlated. In Section 3 we report on national initiatives to adopt fitters' and labourers' agreed national basic hourly wages as the comparative basis for setting the minimum expected rates of hourly pay of pieceworkers of average ability, the piecework percentage. Accordingly, we obtain robust standard errors for the timeworker/ pieceworker equations using seemingly unrelated regression (SUR) estimation. ${ }^{18}$

As in expressions (1) and (4), we present our results for the two pay groups in terms of weekly real earnings and their two component parts, weekly hours and hourly real earnings. We concentrate on wage/hours-unemployment semi-elasticities. ${ }^{19}$

The weekly earnings results in Table 5 present a relatively simple picture. ${ }^{20}$ Weekly real earnings of both timeworkers and pieceworkers are highly procyclical. Results based on the national rate of unemployment do not differ significantly from those based on district rates. A one point increase in the rate of unemployment is associated with decreases of between $0.6 \%$ and $1 \%$ in weekly real earnings. The results

\footnotetext{
${ }^{18}$ We obtain simultaneous equation estimates with robust standard errors using STATA's suest postestimation command.
}

${ }^{19}$ In our related work (Hart and Roberts, 2012), we investigate the issue of possible biases due to within-occupation heterogeneity. We argue that this is likely to be small.

${ }^{20}$ We do not show results with respect to the shift dummy, $D_{t}$. Throughout, It is generally insignificant with no bearing on our key findings. 
with respect to district unemployment rates suggest - albeit with large standard errors that northern weekly earnings procyclicality was stronger than for southern/midland districts.

As shown in Figure 2, weekly hours of work were procyclical in both northern and southern/midland districts. Therefore, we would expect that hours' fluctuations would importantly contribute to weekly earnings procyclicality. In the case of timeworkers, Table 6 reveals that this is unequivocally true. There is one caveat. While the timeworker results based on national unemployment imply no distinction between the north and the south/midlands, those based on district unemployment rates suggest that timeworkers' hours in northern districts were more procyclical than further south. Weekly hours of pieceworkers display cyclicality on a par with timeworkers. But this is not due to a uniform reaction across districts. Especially using district unemployment rates, hours fluctuations among northern pieceworkers are significantly more procyclical than among their south/midlands counterparts.

The microeconometric literature on real earnings cyclicality has been most concerned with hourly, not weekly, real earnings. Our EEF outcomes in this dimension are shown in Table 7.

In respect of timeworkers, they underscore the earlier findings of Hart and Roberts (2012), viz. the hourly real pay of engineering timeworkers was more or less everwhere acyclical during the Great Depression. This is firmly the case in respect of standard hourly rates of pay. When we incorporate overtime working there is some 
indication that real hourly earnings were very weakly procyclical. But pieceworkers made up more than half the workforce in the EEF and here the hourly earnings outcomes tell a different story. First, at national district level, pieceworkers' real hourly earnings are significantly procyclical. A one point increase in the rate of unemployment is associated with decrease of abut one-third of $1 \%$ in hourly real earnings. This semielasticity is lower than found in more contemporary studies where a point rise in unemployment is typically found to be associated with, at least, a $1 \%$ fall in hourly real earnings (Pissarides, 2009). However, the results with respect to the north-south split show that northern districts serve to lower the overall hourly earnings response. Based on district unemployment rates, the semi-elasticity is found to be significantly smaller in northern compared to southern/midland districts. Including the northern slope dummy alters the estimated wage-unemployment semi-elasticity from -0.34 to -0.53 . While this is roughly half the size of modern studies it nevertheless tells us that the hourly real earnings of nearly two-thirds of the blue collar engineering workforce in the regions of Britain with the most modern industries experienced quite strong real earnings procyclicality in the Great Depression.

\section{Discussion}

In equation (3), we identify four main components of timeworkers' weekly real earnings that were susceptible to business cycle influences - basic hourly real wages, the share of overtime hours within total hours, the overtime premium, and total weekly hours of work. We find that the first three of these variables displayed little or no cyclical variability. Hourly basic real wages, strongly conditioned by national 
agreements, were acyclical while hourly real earnings, that include the effects of overtime, were very weakly procyclical. Only weekly hours responded strongly, and procyclically, to the national and district unemployment changes.

Why were timeworkers' hourly real earnings unresponsive to the business cycle fluctuations? Product and consumer prices both fell by $13.5 \%$ and $12.1 \%$ between 1928 and 1934 (Hart and Roberts, 2012). Minimum basic money time rates were set by national agreement for fitters and labourers and these rates were generally adopted as a basis for setting minimum time rates across occupations. For the whole of our period, the nationally agreed minimum rates were held constant (see Knowles and Hill, 1954, Table 3). So, while basic money rates above the agreed floors were undoubtedly reduced in response to the 1929 downturn, cuts were generally constrained by the minimum rates. The net effect was that basic real time rates were acyclical. Since, at the start of the Depression, cuts in timeworkers' weekly hours reduced the share of overtime, falls in hourly earnings could be achieved via this route. However, as is clear from Figure 2, the scope for such reductions was limited because, in most districts, short-time working set in rapidly. There was, however, some limited procyclical effect on timeworkers' hourly real earnings as shown in Table 7. In the few districts were overtime survived, hourly earnings were further reduced by the cut in the overtime premium in 1931.

Under these circumstances, cutting weekly hours of timeworkers offered the only major labour cost response available to employers. From an early stage during the economic downturn, engineering companies went on to short-time working schedules in 
most districts, though especially in the north. This served to reduce payroll costs, lower output in line with falling demand, and may have helped to increase marginal product given decreasing returns. Of course, there would have been significant offsetting cost increases related to plant underutilization. On the supply side, reductions in hours and associated falls in take home pay were unlikely to be strongly resisted by workers and their unions. Prospects of alternative employment were virtually zero, especially in the exceptionally high unemployment districts of the north. Skilled blue-collar workers, who had typically served 5-year apprenticeships, faced the prospect of serious depreciation in their human capital given poor expectations of re-employment in the short term. And, despite increases in unemployment benefits in the interwar period, social security provision for households suffering the loss of their main wage earner was far less developed than in the contemporary economy.

Interestingly, the lack of timeworkers' hourly real earnings responses applied to both northern and southern/midland engineering districts. Differences in industrial composition played no major role, therefore. This is consistent with a dominant influence of time-rate setting between the EEF and national unions. From Table 6 we find that, in respect of district unemployment rates, weekly hours changes - and therefore weekly earnings changes - were more significantly procyclical in the north compared to the south/midlands. This almost certainly did reflect an industrial compositional effect.

Turning to pieceworkers, the first expression on the right hand side of equation (7) contains all the elements of timeworkers' hourly earnings with the addition of the 
pieceworkers' percentage markup. The main component of the markup, the nationally agreed piecework percentage was reduced in 1931 from one-third to one-quarter of an equivalent timeworker's basic wage rate. The associated downward adjustment of piece rates clearly constituted a procyclical effect on pieceworkers' earnings. This is only a partial story, however. As we note in Section 5, reductions in pieceworkers hourly earnings relative to those of timeworkers commenced two years before 1931.

This leaves the last two pieceworker expressions in equation (7). One of these, changes in the length of total weekly hours, played a role similar to that of timeworkers and we know from Table 6 that weekly hours were procyclical for pieceworkers, though more strongly so in northern districts. The other is $\frac{\partial \phi_{j d t}}{\partial U_{t}}\left(\ln p_{j d t}\right)$ which represents the hourly earnings effect of the business cycle of changes in hourly productive work intensity. Piecework pay depends not only on piece prices per unit of output but also on the number of units of output produced per time period. To the extent that productive workflow reduced through a short-fall in demand, the associated drop in work intensity would have negatively impacted on both hourly and weekly money earnings of pieceworkers. Moreover, this effect was potentially large because it acted on all parts of the elements that comprise hourly pay, as itemised in equation (6).

Our data do not allow us to observe changes in hourly productivity on pieceworkers' hourly real earnings cyclicality. However, a strong indirect piece of evidence relates to industrial composition. Pieceworking predominated in southern/midland districts because it was a payments system most suited to this 
region's modern engineering activity. These included the parts production of cars, cycles, aircraft, and sundry electrical goods. In Section 3, we report on evidence that changes in hourly productivity in direct reponse to business conditions were a strong feature of car production in the EEF. South/midlands pieceworkers' hourly real earnings were strongly procyclical and significantly more so than those of their northern counterparts who worked in more traditional engineering sections.

During the early years of the Depression cycle, the downward stickiness of hourly time-rated wages and the relatively greater flexibility of productivity-based piece rates resulted in a fall in the price of piecework relative to equivalent timework (see Figures 4 and 5). This would have encouraged employers, where feasible, to substitute into piecework. The percentages of pieceworkers to total workers shown in Figure 1 are in line with this expectation. 


\section{References}

Arrowsmith, J. and Marginson, P. (2010) The decline of incentive pay in British manufacturing, Industrial Relations Journal 41, 289-311.

Brown, C. (1990) Firms' choice of method of pay, Industrial and Labor Relations Review 43, 165S-182S.

Feinstein, C.H. (1972) National income, expenditure and output of the United Kingdom 1855-1965, Cambridge, Cambridge University Press.

Hart, R.A. and MacKay, D.I. (1975) Engineering earnings in Britain, 1926-1938, Journal of the Royal Statistical Society (Series A), 138, 32-50.

Hart, R.A. (2008) Piece work pay and hourly pay over the cycle. Labour Economics 15, 1006-1022.

Hart, R.A. and Roberts, J.E. (2012) Real wage cyclicality and the Great Depression: evidence from British engineering and metal working firms, Oxford Economic Papers (forthcoming).

Helper, S., Kleiner, M.P., and Wang, Y. (2010) Analyzing compensation methods in manufacturing: piece rates, time rates, or gain sharing? NBER Working Paper Series, \#16540.

Holmstrom, B. and Milgrom, P. (1991) Incentive contracts, asset ownership, and job design, Journal of Law, Economics, and Organization 7, 24 - 52 (Special Issue).

Knowles, K.G.J.C. and Hill, T.P. (1954) The structure of engineering earnings, Bulletin of the Oxford University Institute of Statistics, 16, 272-328.

Knowles, K.G.J.C. and Robertson, D.J. (1951) Earnings in engineering, 1926 - 1948, Bulletin of the Oxford University Institute of Statistics, 13, 179-200.

Pencavel, J. (1977) Work effort, on-the-job screening, and alternative methods of remuneration, Research in Labor Economics, 1, 225-258. 
Pissarides, C A. (2009) The unemployment volatility puzzle: is wage stickiness the answer? Econometrica 77, 1339-1369.

Seiler, E. (1984) Piece rate vs. time rate: the effect of incentives on earnings, The Review of Economics and Statistics, 66, 363-376.

Wigham, E. (1973) The power to manage. A history of the Engineering Employers' Federation. London: Macmillan. 
Figure 1 Percentages of pieceworkers to total workers, 1927 - 1937 (EEF data)

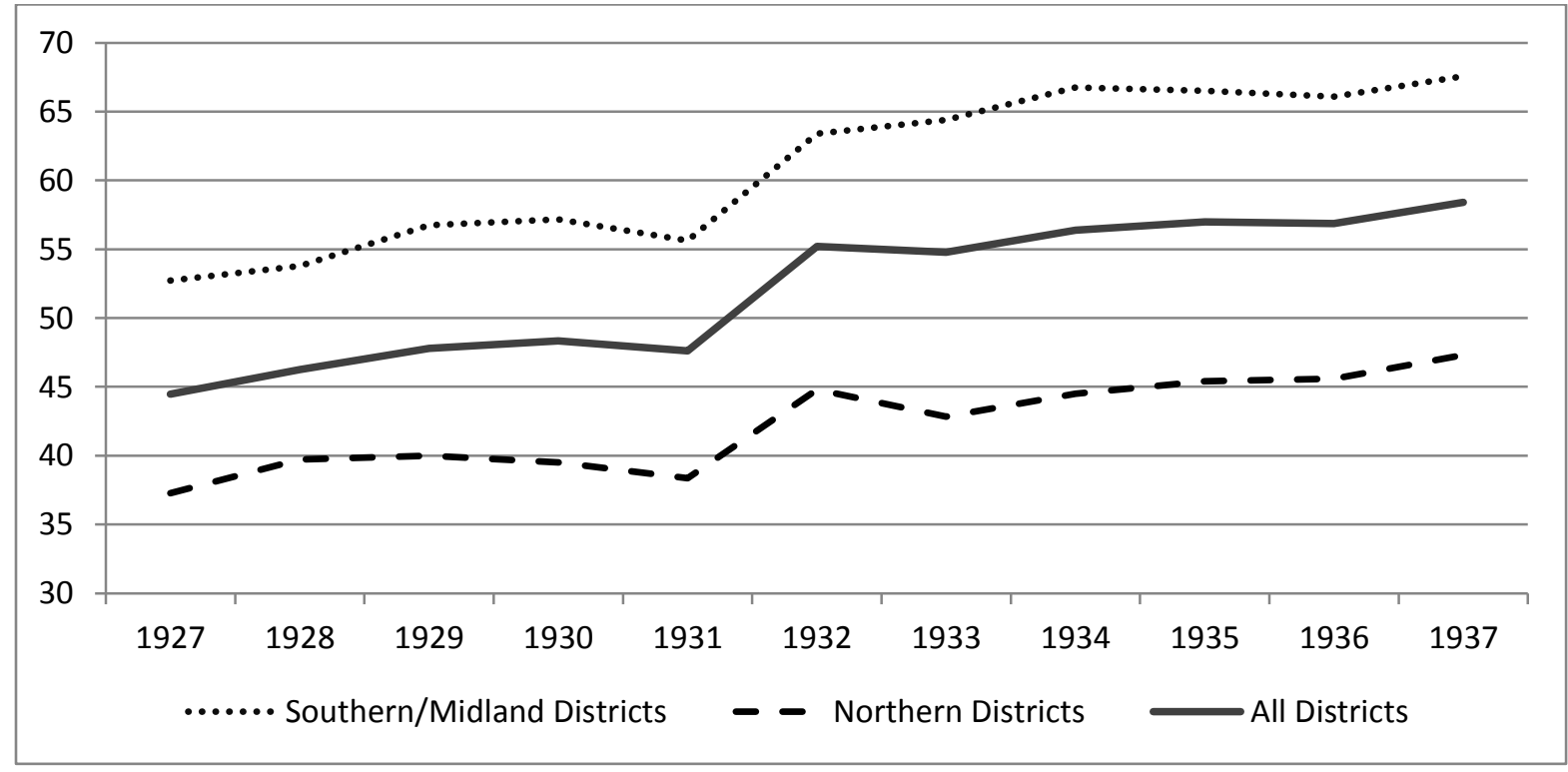

Figure 2 Weekly hours of timeworkers and pieceworkers, 1927 - 1937 (EEF Data)

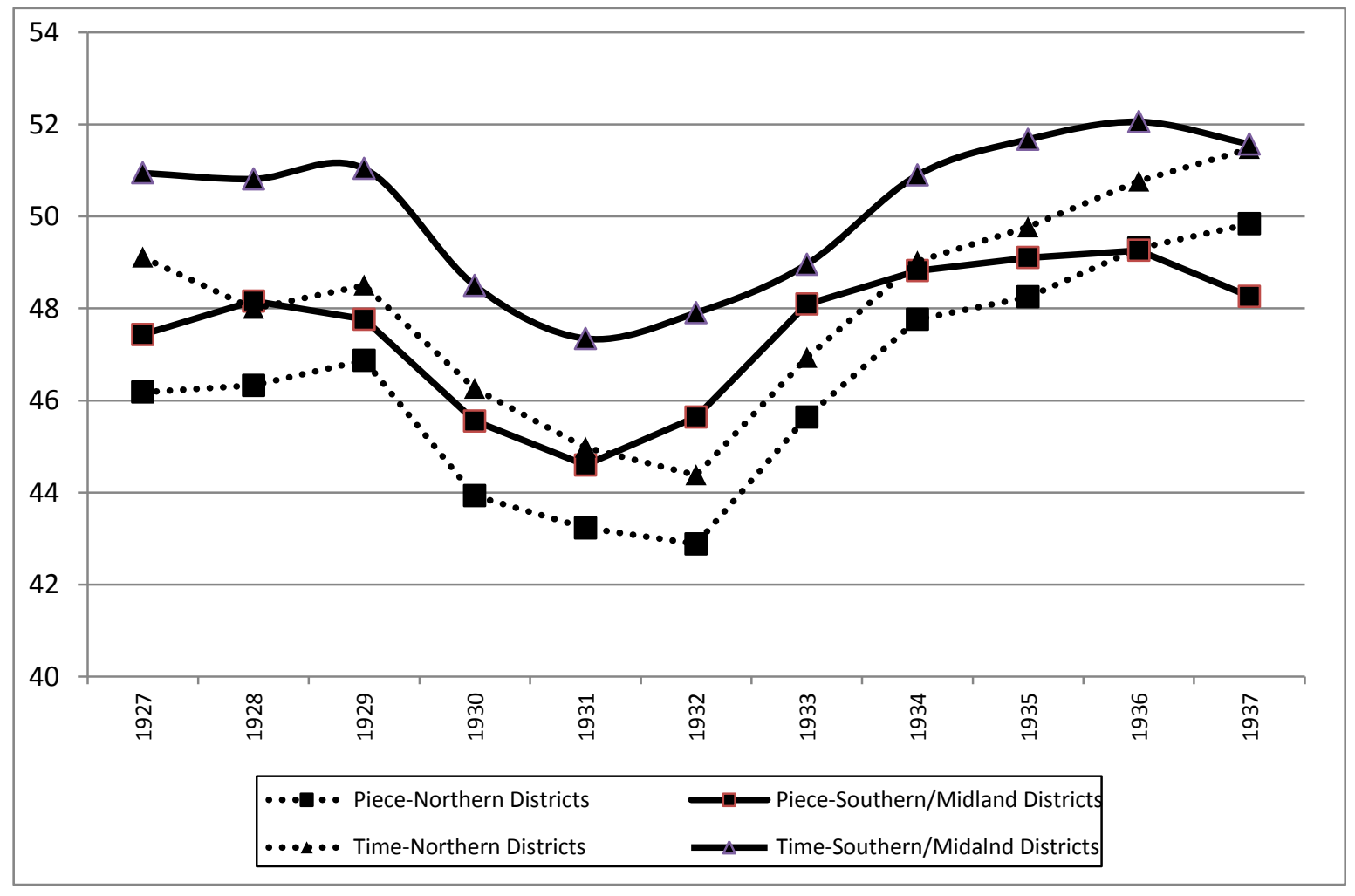


Figure 3 Unemployment rates in EEF districts, 1927 - 1937

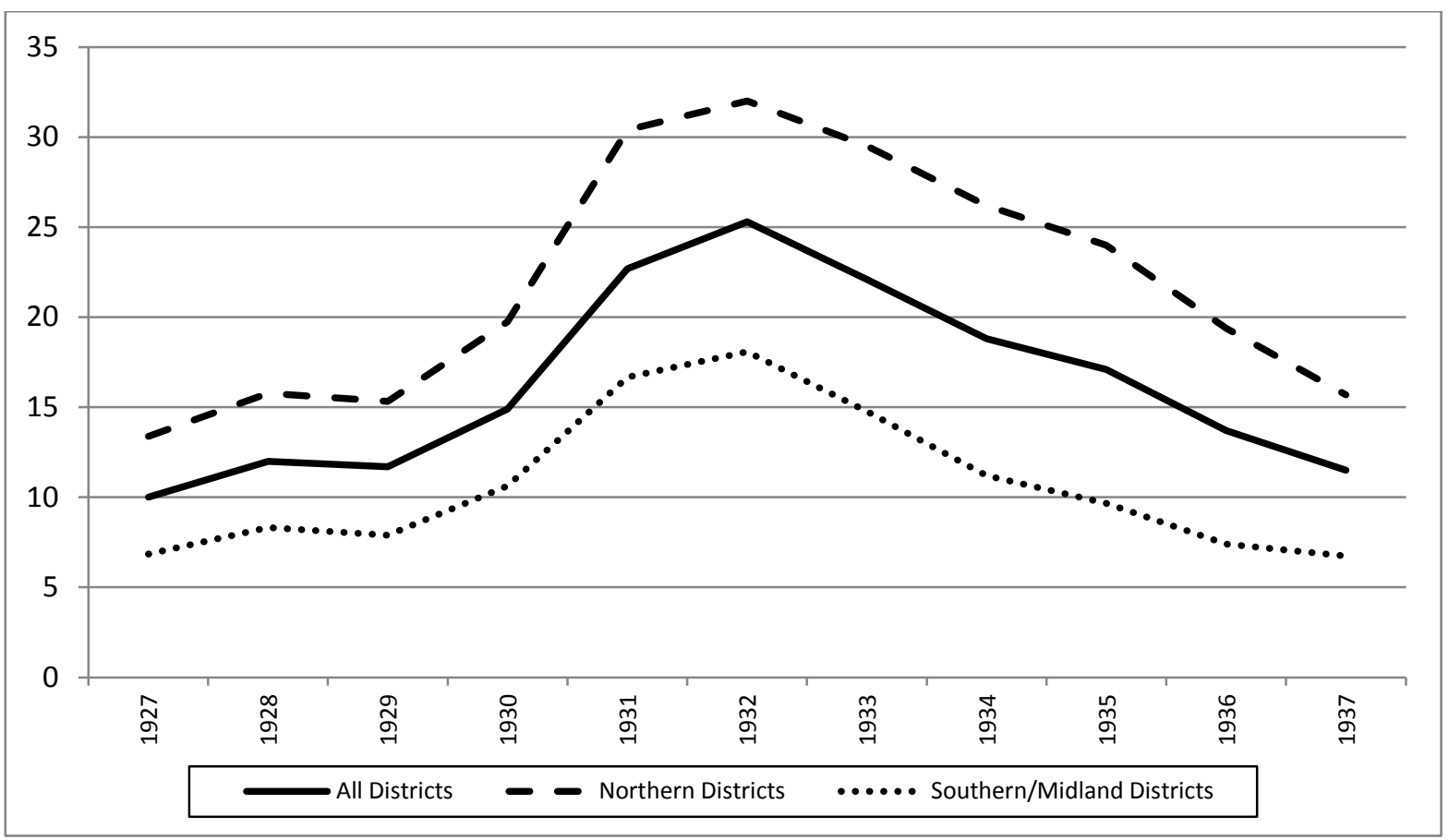

Figure 4 Piecework-timework differentials in hourly earnings, 1927-1937

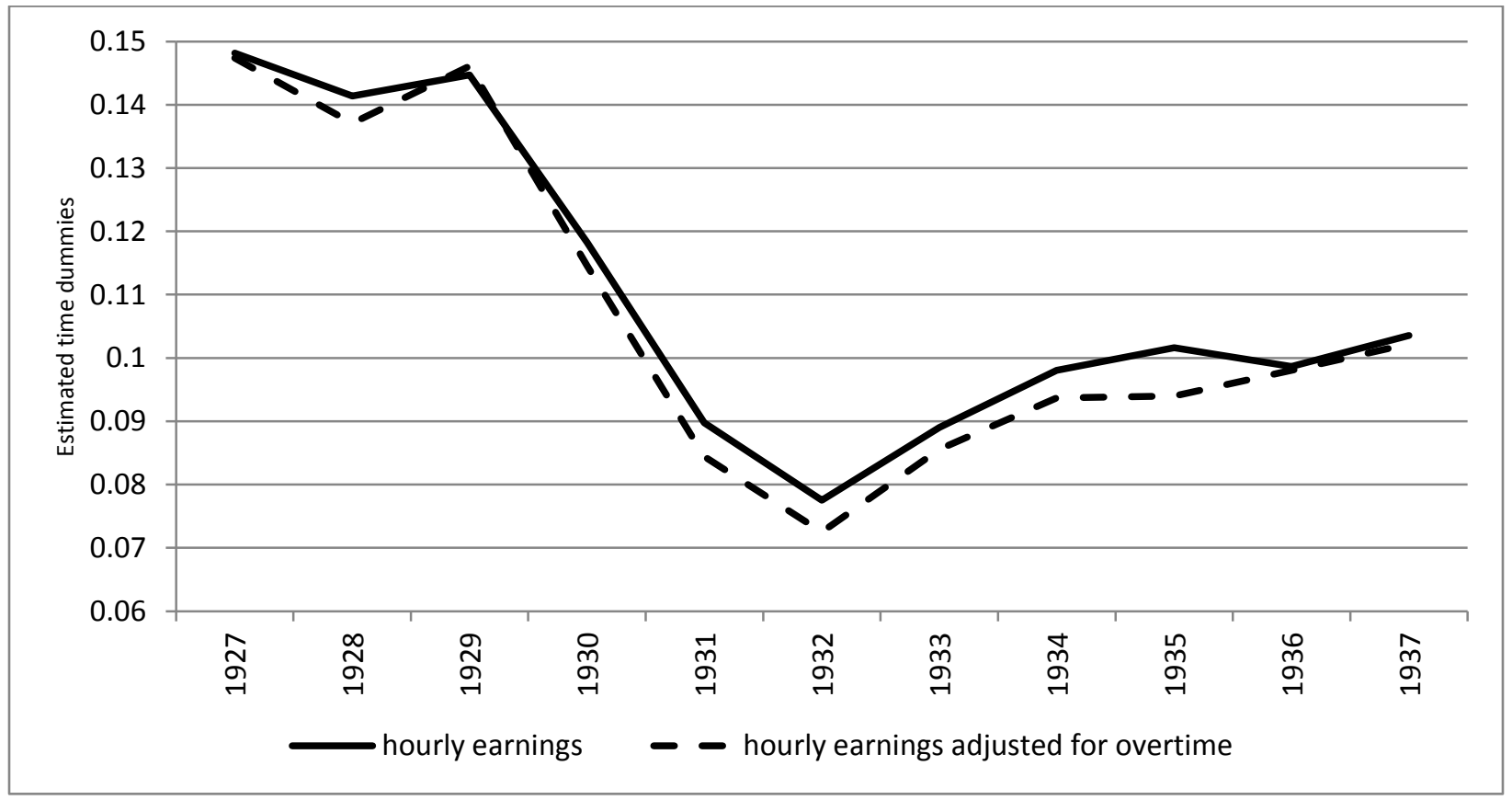


Figure 5 Percentage by which piece-rate hourly wages exceed time-rate hourly wages (turners)

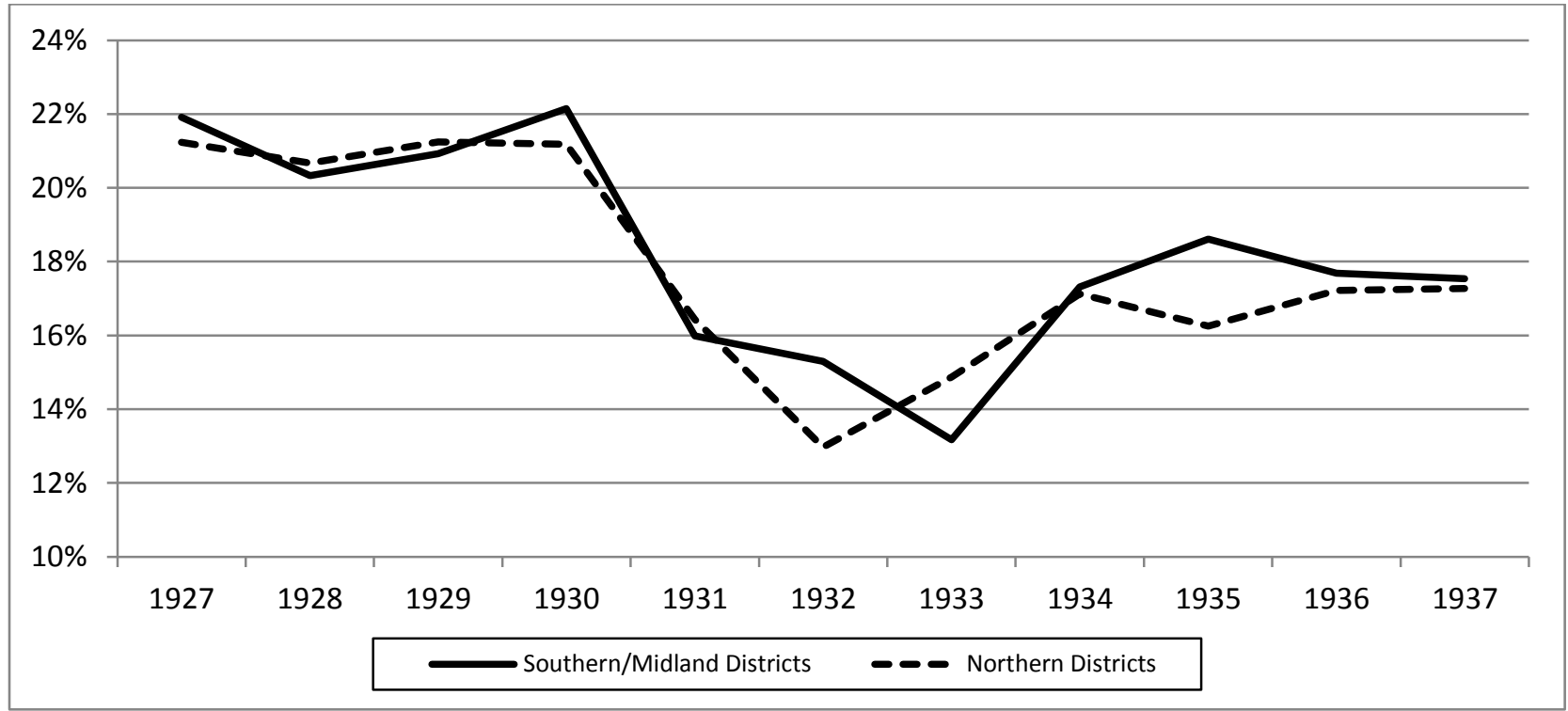

Notes: Average hourly earnings adjusted for overtime premia.

Table 1 EEF blue-collar occupations, and district classification

Occupations Coppersmiths; Fitters; Fitters (other than skilled); Fitters (skilled); Toolroom Fitters; Machinemen (rated at or above fitter's rate); Machinemen (rated below a fitter's rate); Moulders; Moulders (loose pattern); Patternmakers; Platers/Riveters/Caulkers; Sheet Metal Workers; Turners; Labourers.

\begin{tabular}{ll}
\hline Northern & Aberdeen; Blackburn; Bolton; Burnley; Dundee; Halifax; Hull; Liverpool; \\
districts* & Manchester; North East Coast; Northern Ireland; North West Scotland, \\
& Oldham; Preston, Rochdale; Sheffield; Wigan.
\end{tabular}

Southern/Midland Bedford; Burton, Coventry; Derby; Leicester; Lincoln; London; North districts* Staffs, Nottingham; West of England; West Midlands.

Note: * All EEF districts for which we have matching unemployment rates. Most of the district unemployment rates are obtained from Hart and MacKay (1975). They coincide with EEF districts by combining data on male unemployment and total insured workers taken from the Local Unemployment Index. A few district series are obtained from issues of the Ministry of Labour Gazette. 
Table 2 Recovery from the Depression - timeworkers' pay and hours 1930/33 to 1934/37: selected EEF districts and sections

\begin{tabular}{|c|c|c|c|c|c|c|}
\hline & \multicolumn{2}{|c|}{$\begin{array}{c}\text { Average real standard wages } \\
\text { (coefficients of variation) in } \\
\text { pence per hour }\end{array}$} & \multirow[t]{2}{*}{$\begin{array}{c}\text { Percentage } \\
\text { changes }\end{array}$} & \multicolumn{2}{|c|}{ Average weekly hours } & \multirow[t]{2}{*}{$\begin{array}{c}\text { Percentage } \\
\text { changes }\end{array}$} \\
\hline & 1930-1933 & 1934-1937 & & $1930-1933$ & 1934-1937 & \\
\hline \multicolumn{7}{|l|}{ DISTRICTS } \\
\hline Coventry & $3.61(0.28)$ & $4.03(0.24)$ & 11.63 & $49.79(0.02)$ & $51.26(0.04)$ & 2.95 \\
\hline North East Coast & $3.52(0.14)$ & $3.77(0.14)$ & 7.10 & $46.79(0.04)$ & $50.86(0.04)$ & 8.70 \\
\hline Halifax & $3.45(0.13)$ & $3.61(0.13)$ & 4.64 & $44.19(0.05)$ & $51.27(0.06)$ & 16.02 \\
\hline \multicolumn{7}{|c|}{ ENGINEERING SECTIONS } \\
\hline Motors, cars, cycles & $3.40(0.20)$ & $3.95(0.23)$ & 16.18 & $51.73(0.08)$ & $51.70(0.03)$ & -0.06 \\
\hline Marine Engineering & $3.55(0.15)$ & $3.89(0.14)$ & 9.58 & $46.19(0.04)$ & $49.08(0.02)$ & 6.26 \\
\hline $\begin{array}{l}\text { Textile machine } \\
\text { manufacture }\end{array}$ & $3.29(0.17)$ & $3.61(0.15)$ & 9.73 & $39.86(0.09)$ & $45.24(0.03)$ & 13.50 \\
\hline
\end{tabular}


Table 3 Percentage of pieceworkers within total workforce by section: EEF, 1927-1937

\begin{tabular}{llll}
\hline Section & $\%$ & Section & $\%$ \\
\hline Motors (commercial) & 84.0 & Instrument makers & 50.4 \\
\hline Motors (cars, cycles etc.) & 71.0 & Scale, beam etc. & 50.0 \\
\hline Aircraft manufacture & 70.5 & Marine engineering & 49.9 \\
\hline Locomotive manufacture & 66.0 & Tank and gasholder makers & 42.6 \\
\hline Vehicle builders & 65.9 & Construction engineering & 41.3 \\
\hline General engineering (heavy) & 62.9 & Sheet metal working & 40.6 \\
\hline Gas meter makers & 62.7 & Founders & 39.4 \\
\hline Electrical engineering & 59.6 & Miscellaneous & 35.8 \\
\hline Agricultural engineering & 59.5 & Allied trades & 35.5 \\
\hline Machine tool makers & 59.4 & Coppersmiths & 35.3 \\
\hline Telephone manufacture & 53.2 & Lift manufacture & 32.3 \\
\hline Textile machinery makers & 52.0 & Brassfounders & 29.9 \\
\hline Boiler makers & 51.4 & Drop forgers & 21.1 \\
\hline General engineering (light) & 50.8 & Lamp manufacture & 9.1 \\
\hline & All sections: 57.4 & \\
\hline
\end{tabular}


Table 4 Weekly hours and overtime shares by Northern and Southern/Midland EEF districts: 1929 and 1932

\begin{tabular}{|c|c|c|c|c|c|c|}
\hline & \multicolumn{3}{|c|}{ TIMEWORKERS } & \multicolumn{3}{|c|}{ PIECEWORKERS } \\
\hline & 1929 & 1932 & $\%$ Change & 1929 & 1932 & $\%$ Change \\
\hline \multicolumn{7}{|l|}{ WEEKLY HOURS } \\
\hline Northern Districts & 48.1 & 43.7 & -9.1 & 46.3 & 43.0 & -7.1 \\
\hline Southern/Midland Districts & 51.0 & 47.7 & -6.5 & 48.0 & 45.6 & -5.0 \\
\hline \multicolumn{7}{|l|}{ SHARE OF OVERTIME (\%) } \\
\hline Northern Districts & 3.9 & 0.3 & - & 2.4 & 0.1 & - \\
\hline Southern/Midland Districts & 8.1 & 3.3 & - & 3.6 & 0.5 & - \\
\hline
\end{tabular}

Note: for districts in the north and in south/midlands, see Table 1. 
Table 5 Weekly real earnings semi-elasticities, 1927-1937 (SUR estimates)

\begin{tabular}{|c|c|c|c|c|}
\hline \multirow{2}{*}{$\begin{array}{l}\text { UNEMPLOYMENT } \\
\text { National EEF unemployment } \\
\text { rate }\end{array}$} & \multicolumn{2}{|c|}{ TIMEWORKERS } & \multicolumn{2}{|c|}{ PIECEWORKERS } \\
\hline & $\Delta \boldsymbol{U}_{t}$ & $\Delta U_{t} D_{t}$ & $\Delta \boldsymbol{U}_{t}$ & $\Delta U_{t} D_{t}$ \\
\hline & $\begin{array}{c}-0.811^{* *} \\
(0.260)\end{array}$ & - & $\begin{array}{c}-0.957^{* *} \\
(0.245)\end{array}$ & - \\
\hline & $\begin{array}{c}-0.742 * * \\
(0.278)\end{array}$ & $\begin{array}{l}-0.081 \\
(0.160)\end{array}$ & $\begin{array}{c}-0.889 * * \\
(0.217)\end{array}$ & $\begin{array}{l}-0.099 \\
(0.212)\end{array}$ \\
\hline \multirow[t]{3}{*}{$\begin{array}{l}\text { District EEF unemployment } \\
\text { rates }\end{array}$} & $\Delta U_{d t}$ & $\Delta U_{d t} D_{t}$ & $\Delta U_{d t}$ & $\Delta U_{d t} D_{t}$ \\
\hline & $\begin{array}{c}-0.643 * * \\
(0.153)\end{array}$ & - & $\begin{array}{c}-1.001^{* *} \\
(0.272)\end{array}$ & - \\
\hline & $\begin{array}{l}-0.457 \\
(0.255)\end{array}$ & $\begin{array}{l}-0.172 \\
(0.166)\end{array}$ & $\begin{array}{l}-0.782^{*} \\
(0.348)\end{array}$ & $\begin{array}{l}-0.229 \\
(0.215)\end{array}$ \\
\hline
\end{tabular}

Notes: Robust standard errors in brackets with $* *(*)$ indicating $0.01(0.05)$ significance on two-tail test. Using national unemployment, earnings are deflated by a final output price deflator taken from Feinstein (1972). Using district unemployment, price deflation obtained through crosssection and time-series dummy variables. See Table 2 for the make-up of the two district groups. Regressions include controls for occupation, year, and district fixed effects. Using all districts there are 2906 timeworker observations and 2410 pieceworker observations. For northern districts there are 1963 timeworker and 1357 pieceworker obervations and the respective numbers of observations in southern/midland regions are 943 and 1053. 
Table 6 Weekly hours semi-elasticities, 1927-1937 (SUR estimates)

\begin{tabular}{|c|c|c|c|c|}
\hline \multirow{2}{*}{$\begin{array}{l}\text { UNEMPLOYMENT } \\
\text { National EEF unemployment } \\
\text { rate }\end{array}$} & \multicolumn{2}{|c|}{ TIMEWORKERS } & \multicolumn{2}{|c|}{ PIECEWORKERS } \\
\hline & $\Delta \boldsymbol{U}_{t}$ & $\Delta U_{t} D_{t}$ & $\Delta \boldsymbol{U}_{t}$ & $\Delta U_{t} D_{t}$ \\
\hline & $\begin{array}{c}-0.667 * * \\
(0.161)\end{array}$ & - & $\begin{array}{c}-0.655^{* *} \\
(0.228)\end{array}$ & - \\
\hline & $\begin{array}{c}-0.646 * * \\
(0.150)\end{array}$ & $\begin{array}{l}-0.025 \\
(0.112)\end{array}$ & $\begin{array}{l}-0.490 * \\
(0.213)\end{array}$ & $\begin{array}{l}-0.242 \\
(0.177)\end{array}$ \\
\hline \multirow[t]{3}{*}{$\begin{array}{l}\text { District EEF unemployment } \\
\text { rates }\end{array}$} & $\Delta U_{d t}$ & $\Delta U_{d t} D_{t}$ & $\Delta U_{d t}$ & $\Delta U_{d t} D_{t}$ \\
\hline & $\begin{array}{c}-0.555^{* *} \\
(0.162)\end{array}$ & - & $\begin{array}{c}-0.657^{* *} \\
(0.241)\end{array}$ & - \\
\hline & $\begin{array}{l}-0.367 \\
(0.260)\end{array}$ & $\begin{array}{l}-0.174 \\
(0.154)\end{array}$ & $\begin{array}{l}-0.241 \\
(0.300)\end{array}$ & $\begin{array}{l}-0.424^{*} \\
(0.190)\end{array}$ \\
\hline
\end{tabular}

Notes: Robust standard errors in brackets with ${ }^{* *}(*)$ indicating $0.01(0.05)$ significance on two-tail test. See Table 2 for the make-up of the two district groups. Regressions include controls for occupation, year, and district fixed effects. Numbers of observations are as in Table 5. 
Table 7 Hourly real wage semi-elasticities, 1927-1937 (SUR estimates)

STANDARD HOURLY WAGES

HOURLY WAGE EARNINGS

\begin{tabular}{|c|c|c|c|c|c|c|}
\hline \multirow{2}{*}{$\begin{array}{l}\text { UNEMPLOYMENT } \\
\text { National EEF } \\
\text { unemployment rate }\end{array}$} & \multicolumn{2}{|c|}{ TIMEWORKERS } & \multicolumn{2}{|c|}{ TIMEWORKERS } & \multicolumn{2}{|c|}{ PIECEWORKERS } \\
\hline & $\Delta \boldsymbol{U}_{\boldsymbol{t}}$ & $\Delta U_{t} D_{t}$ & $\Delta \boldsymbol{U}_{t}$ & $\Delta U_{t} D_{t}$ & $\Delta \boldsymbol{U}_{\boldsymbol{t}}$ & $\Delta U_{t} D_{t}$ \\
\hline & $\begin{array}{c}0.030 \\
(0.090)\end{array}$ & - & $\begin{array}{l}-0.144 \\
(0.119)\end{array}$ & - & $\begin{array}{c}-0.301^{* *} \\
(0.047)\end{array}$ & - \\
\hline & $\begin{array}{c}0.131 \\
(0.122)\end{array}$ & $\begin{array}{l}-0.119 \\
(0.070)\end{array}$ & $\begin{array}{l}-0.096 \\
(0.155)\end{array}$ & $\begin{array}{l}-0.056 \\
(0.085)\end{array}$ & $\begin{array}{c}-0.399 * * \\
(0.120)\end{array}$ & $\begin{array}{c}0.143 \\
(0.118)\end{array}$ \\
\hline \multirow[t]{3}{*}{$\begin{array}{l}\text { District EEF } \\
\text { unemployment rates }\end{array}$} & $\Delta \boldsymbol{U}_{t}$ & $\Delta U_{t} D_{t}$ & $\Delta U_{d t}$ & $\Delta U_{d t} D_{t}$ & $\Delta U_{d t}$ & $\Delta U_{d t} D_{t}$ \\
\hline & $\begin{array}{l}-0.018 \\
(0.041)\end{array}$ & - & $\begin{array}{c}-0.089 * * \\
(0.033)\end{array}$ & - & $\begin{array}{c}-0.344 * * \\
(0.065)\end{array}$ & - \\
\hline & $\begin{array}{l}-0.039 \\
(0.077)\end{array}$ & $\begin{array}{c}0.019 \\
(0.063)\end{array}$ & $\begin{array}{l}-0.090 \\
(0.060)\end{array}$ & $\begin{array}{c}0.001 \\
(0.054)\end{array}$ & $\begin{array}{c}-0.531^{* *} \\
(0.116)\end{array}$ & $\begin{array}{l}0.195^{*} \\
(0.085)\end{array}$ \\
\hline
\end{tabular}

Notes: Robust standard errors in brackets with $*^{* *}(*)$ indicating $0.01(0.05)$ significance on two-tail test. Using national unemployment, earnings are deflated by a final output price deflator taken from Feinstein (1972). Using district unemployment, price deflation obtained through crosssection and time-series dummy variables. See Table 2 for the make-up of the two district groups. Numbers of observations are as in Table 5. 